\title{
USOS E COSTUMES SEXUAIS E A CULTURA DO SEXO DO PERÍODO EDO NAS PINTURAS ERÓTICAS UKIYO-E
}

Monta Hayakawa

Dentre as várias expressões pictóricas do período Edo (1603 - 1867), ukiyo-e é gênero famoso internacionalmente, e quase todos seus pintores produziram obras eróticas a que se chamam shunga. O número remanescente das principais obras eróticas shunga dos pintores ukiyo-e do período Edo está estabelecido em mais de mil, sendo seu formato principalmente de dois tipos: livros impressos e álbuns de imagens soltas; os livros têm em geral três volumes, cada qual com doze ou mais imagens eróticas. Os álbuns, por sua vez, via de regra são conjuntos de doze páginas. Assim sendo, supõe-se que o número de imagens eróticas produzido no período Edo ultrapasse as três mil unidades.

Quando se fala em ukiyo-e shunga, até os dias de hoje, tanto no exterior quanto no próprio Japão, tem-se enfatizado somente ora a representação sexual audaciosa, ora o exagero dos orgãos sexuais masculinos, mas sua peculiaridade certamente não se restringe a apenas esses aspectos, pois nota-se que se trata de um universo extremamente rico e colorido. Em relação às dez caracteristicas do ukiyo-e shunga que aqui aponto, estas já se encontram enumeradas em material de referência ${ }^{1}$ e, assim sendo, gostaria de indicá-las, comparando-as com as da pornografia atual.

(1) "Os protagonistas do ukiyo-e shunga são as pessoas comuns"

Pornographie enquanto tradução de shunga, para os países ocidentais, tem atualmente o significado de "pintura de prostitutas" sendo mais freqüente compreender

1. O material de referência aludido encontra-se no fim do texto, como adendo. 
as mulheres representadas no ukiyo-e shunga principalmente como yûjo (mulher profissional), mas, como todas as mulheres representadas no ukiyo-e vestem sem exceção belíssimos quimonos e são muito bonitas, se não se tiver conhecimento dos vestuários e acessórios femininos correntes no período Edo, não se pode discerni-las como sendo adornadas yûjo ou mulheres outras de apurado senso estético. Em relação a esse aspecto, tal incompreensão não se restringe somente aos estrangeiros, pois atualmente nem os japoneses conseguem discriminar a posição social das mulheres que aparecem no ukiyo-e e, quanto às imagens eróticas, muitos são os que têm uma compreensão errônea sobre os jogos de yûjo e seus clientes das áreas de prazeres ou dos divertimentos de homens ricos ou cultuadores do sexo. Entretanto, quando vamos observando de modo mais concreto uma a uma as pinturas eróticas ukiyo-e, notamos que mais de $90 \%$ dos homens e mulheres que ali aparecem são simplesmente gente comum. Mas o mundo do amor sexual que ali se espraia repetidamente está fundamentado em usos e costumes sexuais cotidianos e comuns de homens e mulheres jovens e velhos do povo.

Obviamente, isso não quer dizer que inexistam representações de yûjo. Quando se fala em áreas de prazeres do período Edo logo vem à mente a famosa Yoshiwara da cidade de Edo, mas, na verdade, em cada rincão do país existiam várias "áreas alegres" oficiais, maiores ou menores, e yûjo de várias categorias ali se reuniam à espera de seus clientes $\mathrm{e}$, por isso, encontram-se também representadas nas pinturas eróticas ukiyo-e. Entretanto, estas não alcançam sequer a proporção de $5 \%$ e, mesmo assim, em sua representação não se tem absolutamente a impressão de se tratar de um mundo especial, fora da cotidianeidade, e, sim, que elas são manipuladas para mostrar mais um dos usos e costumes variados do povo comum.

Ainda, outro equívoco em relação ao pano de fundo representado nas imagens eróticas $u k i y o-e$ diz respeito à interpretação de que se trata de uma representação de uma sociedade afluente e superior, que habita mansões de categorias sociais privilegiadas, e seus usos e costumes sexuais de libertinagens sem peias de pessoas ociosas, mas, como se compreenderá ao se observar, peça a peça, de modo concreto, o cenário principal das pinturas eróticas ukiyo-e é o da sociedade comum em que vive a população comum.

Dizer que se trata de uma representação de usos e costumes da gente comum não significa que o mundo das pinturas eróticas ukiyo-e seja absolutamente enfadonho. É óbvia a variedade das combinações de homens e mulheres; mas, se existem também as de homens com homens e de mulheres com mulheres, é óbvio que, também em relação à idade, haja

2. Yûjo, literalmente "mulher-entretenimento", refere ampla gama hierárquica de ocupações profissionais dentro de uma área de prazeres. A tradução "cortesã" ou "prostituta" nāo corresponde ao termo, embora ainda seja corrente. 
homens e mulheres jovens e que apareçam meninos e meninas, homens e mulheres maduros e até os de idade avançada. Essas combinações e situações também são profusas e variadas; se é óbvio que a sedução parta do homem, existe também grande número de imagens em que a proveniência é de mulheres; se é óbvia a frivolidade amorosa dos proprietários de casas comerciais também se mostra inconstâncias de suas esposas. Assim sendo, o mundo das pinturas eróticas ukiyo-e tentou representar de modo exaustivo os usos e costumes sexuais de todos os homens comuns, podendo-se dizer tratar-se, sem dúvida, de uma representação de uma mandala do amor erótico humano e, mesmo na história da cultura universal, pode-se dizer que é um fenômeno extremamente raro.

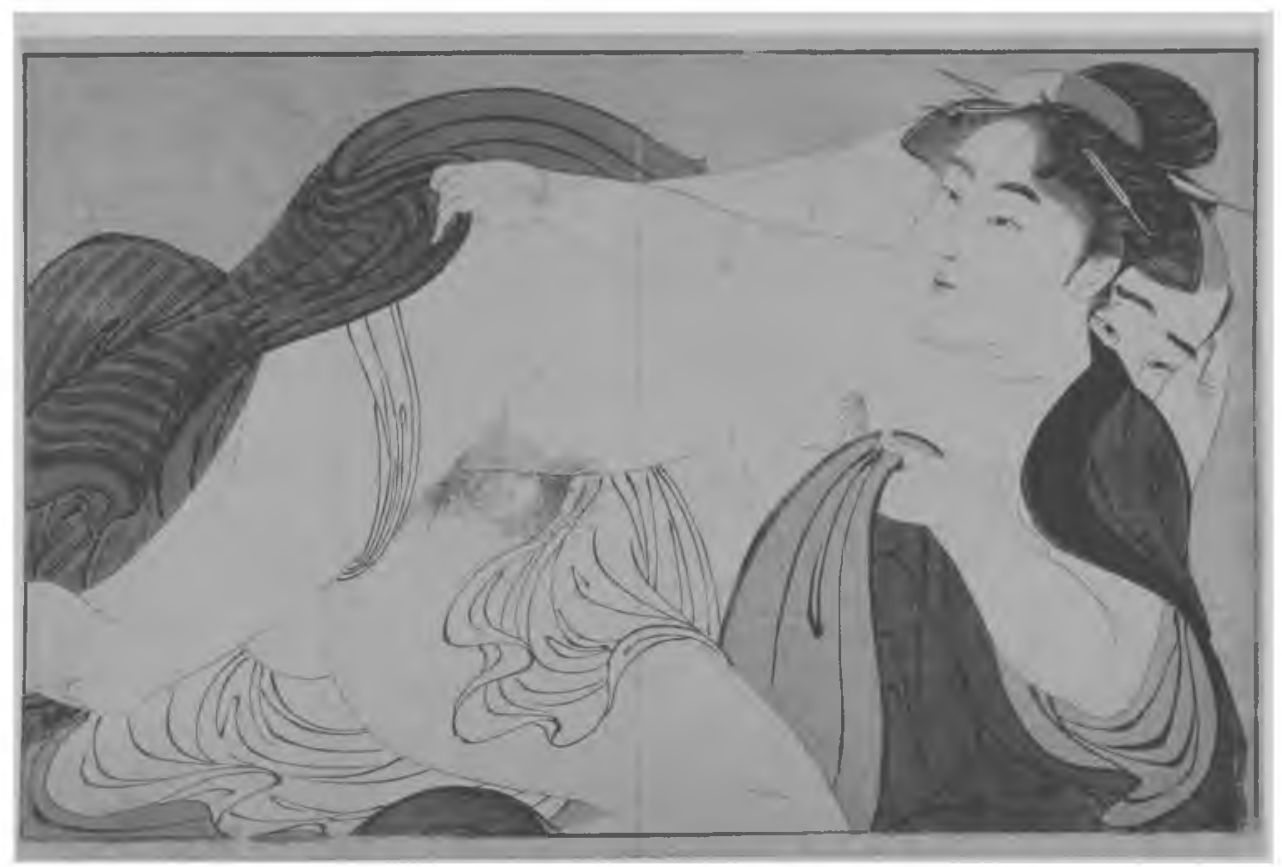

Figura 1. Utamakura (Travesseiro de poemas), $11^{\mathrm{a}}$ imagem, Kitagawa Utamaro (1753 1806), álbum de doze folhas grandes multicoloridas, Tenmei 8 (1788).

Trata-se de uma representação das atividades noturnas de um casal de meiaidade que, embora pobre, se entende muito bem. O rosto da esposa, que tem os dentes pretos $^{3}$, é rechonchudo; uma face de queixo duplo evidencia suas muitas felicidades, uma descontração muscular liga pescoço a ombros, uns braços roliços e carnosos e umas coxas

3. No período Edo, pintar os dentes de preto indicava a condição de mulher casada. 
firmes e fortes apontam certamente a idade madura. $O$ rosto do marido, que pode ser visto atrás das costas da esposa, tem uma aparência miserável, de tão caídos estão seus olhos. Pode-se dizer tratar-se de uma representação em que flutua um sentimento de vida difícil de ser encontrado no ukiyo-e mais geral. O ponto principal desta imagem erótica não se encontra no ápice do intercurso sexual, e sim, na liberdade de poder desenhar uma esposa que se encontra no ato de cobrir seu esposo com uma coberta, achando que ele deveria estar sentindo frio. Literalmente, trata-se de uma esposa "de muitas felicidades" 4

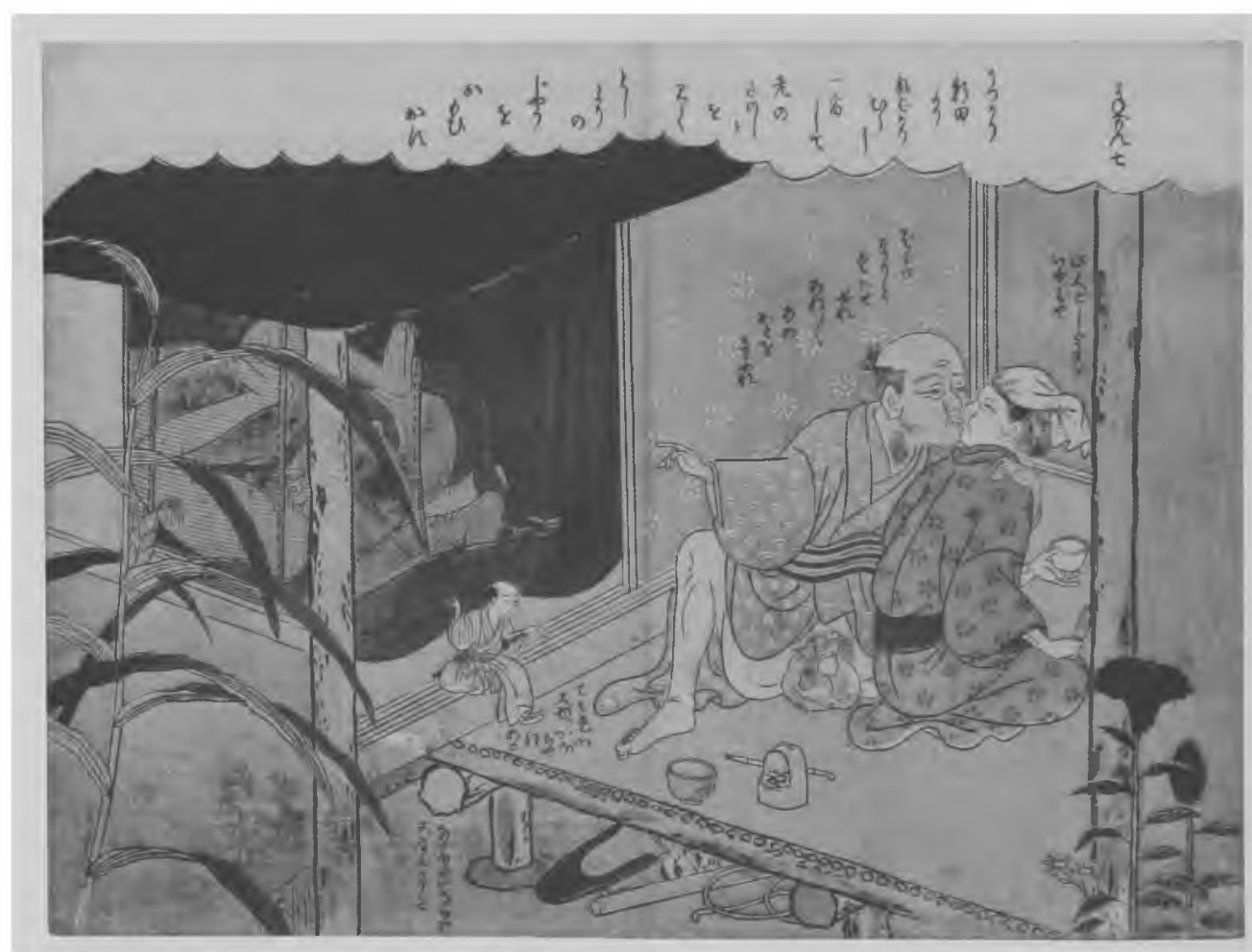

Figura 2. Fûrŷ̂ enshoku Maneemon (O Elegante e Atraente Maneemon), $7^{\mathrm{a}}$ imagem, Suzuki Haranobu (1725? 1770), estampa multicolorida de dimensões médias, álbum de 24 folhas, ano 7 da era Meiwa (1770), coleção Nichibunken.

Trata-se de uma imagem divertida de um casal idoso de família campesina numa noite de verão. Parece que o casal idoso acabou de jantar e está a saborear o chá; e, no interior do mosquiteiro do quarto vizinho, o filho e a esposa já iniciaram mais cedo as

4. Otafuku, literalmente "muitas felicidades", é termo utilizado para indicar "mulher comum, do lar" 
delícias da noite. Entretanto, o tema principal da presente imagem não se encontra nesta cena mas, sim, no casal idoso. Lendo-se o texto inserido dos dois tem-se:

Velho: "Véia, me deixa chupá tua boca. Ah, ah, dá uma escutada naquele barulho!"

Velha: "Ah, aqueles dois, hein? Ai, que vergonha!"

Trata-se de uma cena em que o velhinho, ouvindo os íntimos sons dos dois jovens no quarto vizinho, foi tomado subitamente por um ardor sexual e importuna sua velhinha aproximando-lhe de leve a sua boca. Embora um pouco contrariada, deixa-o sugar sua boca, virando o pescoço em sua direção. Não se trata de uma cena de amor sexual de fato divertida e prazerosa?

(2) "Sexo é riso"

$\mathrm{Na}$ verdade, shunga era chamado, no período Edo, de warai-e (pintura-riso). Compreende-se pintura-riso como uma representação em que se mostra de modo extremamente divertido as atividades sexuais do homem - embora assim também se classificasse a representação sexual satírica -. Na pintura erótica, o amor sexual das pessoas era tratado de modo franco, e a maior parte, tomando-a como objeto de riso, tinha um caráter extremamente cru e direto. Quer dizer, os habitantes do período Edo certamente consideravam mesmo o sexo como objeto de riso.

No período Edo, chamava-se "instrumentos de riso" ao consolo de viúva ou a outros implementos sexuais como capuz-de-pênis, o que demonstra uma visão que liga diretamente o "sexo" ao "riso" Por outro lado, a etimologia pode variar dependendo do caso, mas ainda hoje em vários territórios japoneses são transmitidas as artes populares de danças humorísticas que exageram os órgãos sexuais masculinos. Nas festividades há procissões onde são desfilados objetos construídos em forma de órgãos sexuais masculinos e femininos, transformados em palanquins sagrados a fim de provocar o riso nos participantes. Nessas cerimônias, o ato de rir não era absolutamente nenhum tabu; pelo contrário, o riso de todos servia principalmente a invocar e recepcionar a felicidade geral. Uma história simbólica equivalente seria a do Portal da Caverna Celestial na Rocha (Ama-no Iwato) que consta na obra Relato de Fatos Antigos (Kojiki). Nessa lenda divina, todos os deuses gargalhavam devido à dança da divindade Ama-no Uzume, que expunha sua região púbica; esse exuberante riso é motivo de invocação do retorno total e completo da "Luz" para o mundo e pensa-se que a percepção de ver o sexo como fonte obrigatória de riso e invocação da felicidade foi transmitida de modo ininterrupto desde a antiguidade cultural japonesa. Tal percepção certamente ainda persistia nas profundezas do espírito dos habitantes de Edo, que classificavam a pintura erótica como pintura-riso. E, nos fundamentos da visão do sexo do período Edo, ao mesmo tempo em que coexistia um modo de pensar que afirmava serenamente 
o desejo sexual como fundamental para a humanidade, parece que este sempre esteve acompanhado em algum ponto do "riso"

O "riso" enquanto valor cultural, em geral, é visto como um gênero baixo, mas supõe-se não existir uma cultura que o tenha valorizado tanto quanto a do período Edo. Certamente, no "riso" também existe a baixeza de zombar somente de coisas vulgares ou da ridicularização ao próximo, mas aquele almejado pelas pinturas eróticas ukiyo-e é de outra natureza, pois busca rir de si mesmo através de voltas e voltas que provocam comicidade na equalização humana através do sexo.

Em outras palavras, pode-se pensar que a pintura erótica ukiyo-e é uma expressão pré-moderna tradicional que se transmitiu desde a antiguidade segundo a qual: "o sexo é riso" Os habitantes de Edo expressaram o sexo considerando um "riso" que os incluía a si próprios. O "riso" suaviza o espírito rígido do homem e proporciona uma calma inexprimível para o desejo, de outra forma incontrolável, e a visão que um "sexo" tal qual se vê no ukiyo-e shunga não nos teria talvez legado a nós, sujeitos contemporâneos, uma importante sugestão?

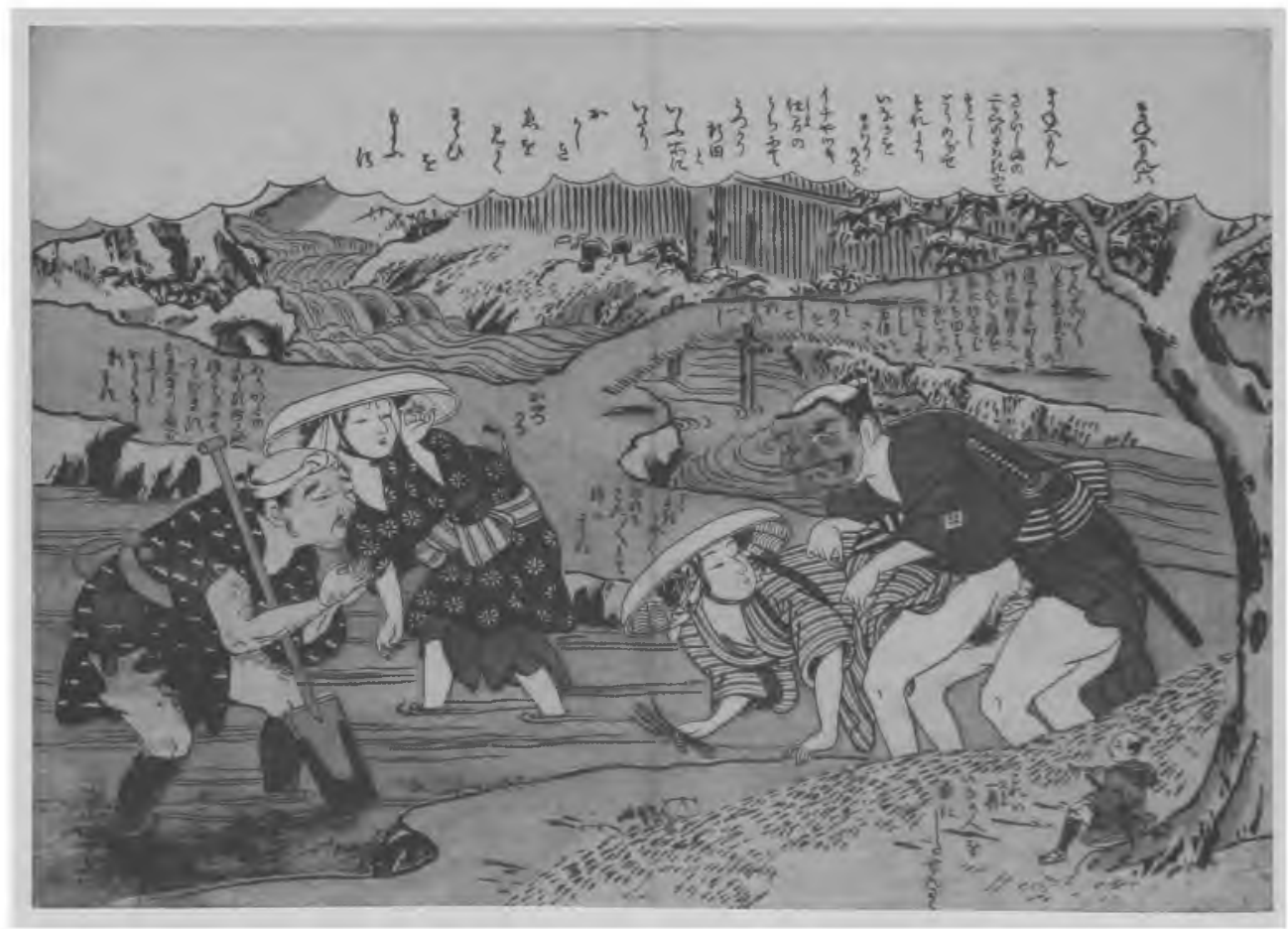

Figura 3 Fûryû enshoku Maneemon (O Elegante e Atraente Maneemon), $6^{\mathbf{a}}$ imagem, Suzuki Haranobu (1725? 1770), estampa multicolorida de dimensões médias, álbum de 24 folhas, ano 7 da era Meiwa (1770), coleção Nichibunken. 
Num lugar em que um casal de agricultores e sua filha se dedicam à plantação, aparece um homem com uma máscara grotesca que, portando uma espada nos quadris, tenta um ato insolente por trás da moça, ocupada a lavrar a terra. Nas palavras do homem mascarado:

Homem: "Delícia, delícia, sou o deus do corvo noturno do pequeno santuário ${ }^{5}$ de Inari. Se me concederdes vossa donzela, farei multiplicar os grãos em grande colheita nesta vossa plantação."

Isto é, este homem, trajando uma máscara amendrontadora, usa de subterfúgios enganosos, tal qual personagem de romance chinês, fingindo ser o deus de Inari. "Yogarasuno kami”よがらすの神 (é um trocadilho para “pássaro noturno" (yogarasu夜鳥) e “fazer o bem" (yogarasu善がらす). Do ponto de vista do vocábulo é um tanto questionável, mas parece que o casal idoso de agricultores acredita completamente nele.

Esposa camponesa: "Ai! que medo!"

Marido camponês: "Oh, que deus dadivoso! Concedo-vos não só minha filha, como também a minha velha. Imploro-vos a mediação benfazeja da divindade Inari!"

Se o agricultor receber a dádiva dos produtos agrícolas, concederá não só a filha, mas também a esposa e, assim, provoca o riso e, por outro lado, quanto ao "yogarasu-no kami" este parte após responder, num trocadilho onomatopaico:

Homem mascarado: "Ah, que bom, que bom! Amanhã também venho, crau-crau!"

Isto é, quando ele fala "Ah, que bom, que bom!" está superpondo uma interpretação: além de ser uma resposta ao chamamento de seu nome, Inari, também está dizendo que a moça é a melhor. E, ainda, quando diz "Amanhã também venho", há um trocadilho entre "venho" (konkon 来ん来ん) e o lamento da raposa (konkon コンコン), que é símbolo da divindade Inari.

Indica-se, assim, um sentimento de superioridade muito peculiar dos habitantes de Edo, que apreciavam zombar dos camponeses. Certamente é uma história simplória de uma crença quase impossível em tal subterfúgio de personagem de romance chinês, o que faz rir ainda mais. Entretanto, se formos apreciar calmamente esta imagem, mais do que dizer que se trata apenas de uma história simplória, será que ela não nos faz sentir certa nostalgia dos antigos contos folclóricos? Nas festividades de plantio de arroz da antiguidade japonesa, é uma parte essencial a inclusão de cantigas que envolvem conteúdos sexuais. Assim, podese pensar que o desejo de uma plantação farta foi a origem de uma metáfora (mitate) que transformou o desabrochar dos brotos em "intercurso sexual" entre homens e mulheres. Tal metáfora, à medida em que foi se desenvolvendo o intelecto humano, parece ter se transformado simplesmente em crença popular, mas, mesmo depois de percebermos seu mecanismo, será que deixaremos de notar que ainda está viva a sensibilidade da antiguidade

5. Massha refere um santuário pequeno que em geral se agrega ao templo principal (honsha). Por associação, nas áreas-de-prazeres, o termo foi utilizado metaforicamente como uma pequena edificação que ortorno de uma maior, ou seja, o papel dos taiko-mochi, guias bajuladores entretenedores. 
nas profundezas do conhecimento humano? O riso da imagem presente não é apenas um riso simplório, pois encontra-se impregnado de um sorriso que provém de tal origem ancestral.

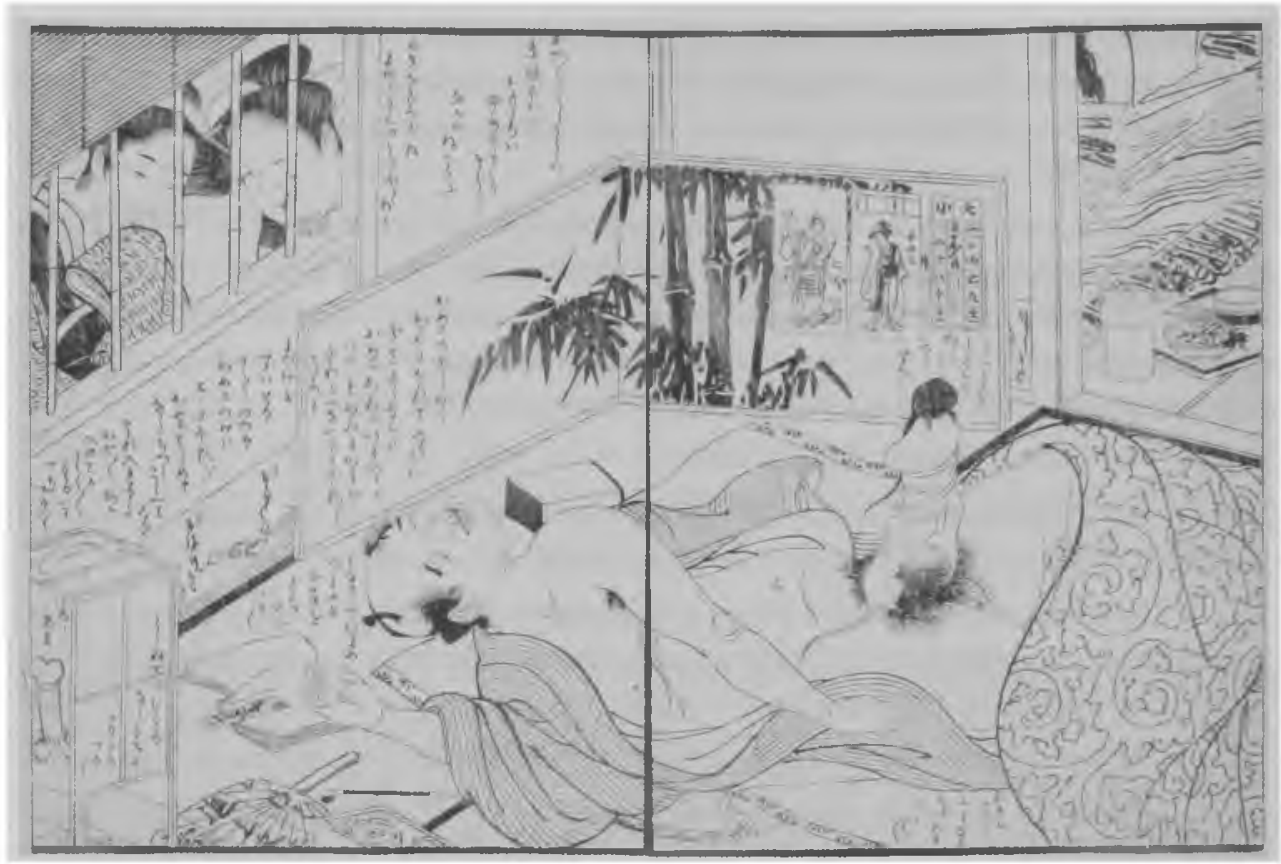

Figura 4. Ehon Jinkôki (Livro Ilustrado de Vigorosas Alegrias Amorosas), $4^{\mathrm{a}}$ imagem do $2^{\circ}$ volume, Katsukawa Shunshô (1726 1792), livro preto e branco de tamanho médio, 3 volumes, ano 1 da era Kansei (1789), coleção Nichibunken.

A presente figura apresenta um homem sozinho numa residência pobre geminada da Cidade Baixa de Edo que sonha durante sua sesta vespertina. Podemos ouvir seu solilóquio:

Solilóquio do homem: "Ah, quero ter uma mulher como a moça do vizinho! Gou-gou! Se for a moça da loja de queijo de soja, melhor ainda! Goukuufuu goukuufuu. (...) És tu que não sabias, até agora, que estavas doidinha por mim. Tu gostas de mim? Também te acho uma bonequinha. Como num tem ninguém, bem, bem, mi deixa lamber um pouco tua boca. Oh, oh, tua boca tem cheiro bão! Se é tua primeira vez, guenta firme! Vou colocar ele. Olha, olha, que pintão mais grudento, shiku, shiku. Haafuugou haafuugou.

Desnecessária qualquer explicação, não é? A feição dormente de lábios entreabertos é negligente, o torso exposto na frente expressa claramente o sonho. E em seu órgão esplêndido totalmente desperto, dois ratos conversam:

Rato branco: "Com a minha mão, dou cinco voltas. Kii-kii-kii..." 
Rato preto: "Vem cá e dá uma olhada. 'Tá saindo um líquido pegajoso, que escorrega!"

O rato preto está agachado em seu prepúcio. Não é sem razão que ele diz: "Que pintão mais grudento, shiku, shiku" Trata-se de mais um artifício para provocar uma gargalhada. Os artificios para o riso não terminam aí, pois da janela, duas senhoras espiam da casa vizinha:

Primeira mulher: "Olha, olha, que coisa incrivel! Seu Itogen parece estar tendo um sonho bem divertido. Que fala mais longa enquanto dorme!"

Segunda mulher: "Que coisa mais grande, né? Acho que tem o tamanho da coisa do Seu Kishirô..."

As mulheres tornam o homem um objeto de exposição. Talvez seja uma cena em que, logo mais, roído pelos dois ratos, o homem logo acordaria. Nas pinturas eróticas japonesas, os objetos de gargalhada são, em sua maioria, homens.

(3) "A gangorra das feições e dos órgãos sexuais"

Diz-se frequentemente que uma das peculiaridades da pintura erótica ukiyo-e é a representação exagerada dos órgãos sexuais masculinos, mas isso se deve à imediata evidência aos olhos pois, se observados friamente, nota-se que também os órgãos sexuais femininos igualmente assim o são. Se assim não o fosse, seria impossível a concretização do amor sexual entre o homem e a mulher. Especialmente em relação à pintura erótica a partir de meados do século XVIII, quando a pintura ukiyo-e tem seu período mais próspero, os órgãos sexuais masculinos e femininos passam a ser representados praticamente na mesma dimensão que suas faces e, além disso, utilizando-se de um modo extremamente minucioso. Ao observarmos esse persistente modo de desenhar, parece que é propositada a ênfase nos órgãos sexuais masculinos e femininos para atrair o apreciador. Se nos concentrarmos somente nesse aspecto, poder-se-ia pensar que a pintura erótica fosse, na verdade, uma expressão exagerada de órgãos sexuais, mas ao se ignorar seu contraponto, incorre-se na minoração de outras peculiaridades da pintura erótica. Quer dizer, está sempre presente uma representação simultânea tanto dos órgãos sexuais quanto das faces. E, ainda, outro ponto importante é que o foco central não se encontra somente na figura feminina, pois há um paralelismo frequente tanto de órgãos sexuais quanto de faces, masculinas e femininas.

Se em uma pintura de folha solta tanto os órgãos sexuais quanto as faces masculinas e femininas numa relação sexual são simultâneas, não haverá como distorcer seus corpos de um modo natural. Se observarmos as pinturas audaciosas de Utamaro ou Hokusai, vemos que, para desenhar de forma simultânea e frontal órgãos sexuais e faces de homens e mulheres, não há como não distorcer, mais ou menos, a representação de seus corpos. Tem sido apontada frequentemente tal distorção acrobática como característica da pintura erótica, 
mas os pintores ukiyo-e não poderiam ter a intenção de desenhar corpos estranhos e, assim, é muito mais razoável pensar que, como resultado da intenção de representar de modo paralelo faces e órgaos sexuais masculinos e femininos no momento da cópula, não teria havido como encontrar, enquanto técnica de pintura, outra forma. Tal aspecto era certamente compreendido pelos habitantes de Edo, como demonstra o seguinte poema senry $\hat{u}^{6}$ :

\section{Casal idiota}

A imitar pintura erótica

Numa caimbra só!

$O$ fato de assim se representar de modo paralelo faces e órgãos sexuais masculinos e femininos no momento da cópula, não poderia levar a pensar, dependendo da interpretação, que se trata de uma expressão tanto simbólica quanto franca de uma verdade realmente profunda da existência humana? Se compreendermos a face humana como um símbolo da "exterioridade" (omote) da vida social, então o órgão sexual seria positivamente seu símbolo de "interioridade" (ura). Se assim for, representa-se com dimensões e minúcias de mesmo nível tanto as "exterioridades" quanto as "interioridades" do homem e da mulher e, além disso, pode-se dizer que o fato de se mostrar em paralelo o modo como se encaraminham reciprocamente expressa simbólica e verdadeiramente uma relação recíproca e complexa de "interioridades" e "exterioridades" do homem, as quais, por mais que tentemos separá-las, são inseparáveis.

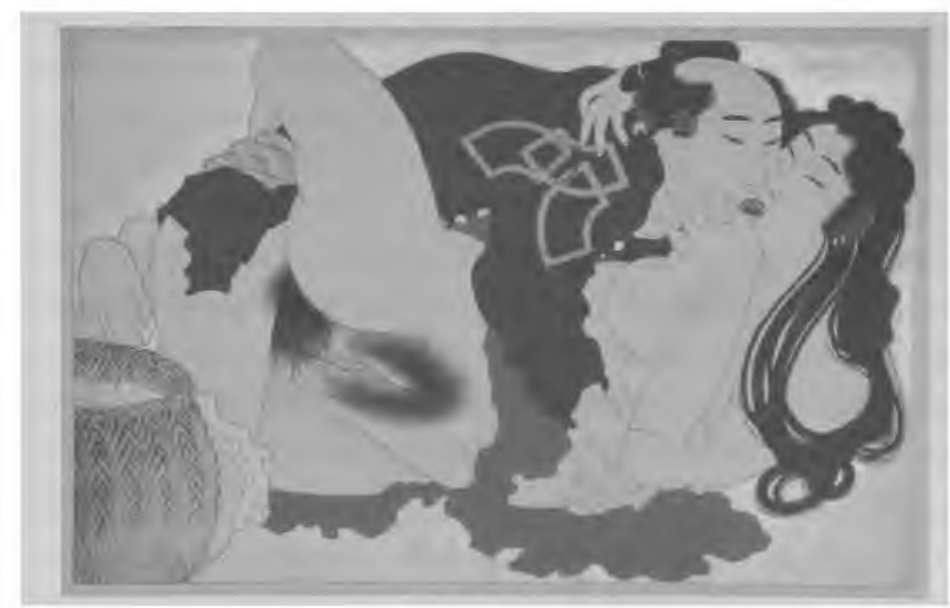

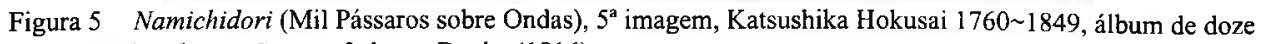
estampas pintadas a mão, ano 3 da era Bunka (1816).

6. Poema composto de 5-7-5 silabas, difere do haicai no teor satírico e voltado à vida cotidiana. 
Trata-se de uma representação de batalha entre uma catadora de pérolas e um pescador, numa orla marítima. Comparando-se este álbum com o texto inserido de uma composição semelhante impressa anteriormente, intitulada Fukujusô (Sob a Sombra de Flores Primaveris), nota-se que se trata de dois apaixonados. Entretanto, a mulher é muito voraz, sendo objeto de muitos rumores com muitos homens. A cena mostra este homem, que já havia ouvido rumores tais, a demandar explicações de modo rude, mas a mulher, tratando de modo evasivo suas suspeitas, tenta forçá-lo aos jogos amorosos.

A caracteristica da presente composição encontra-se no tratamento em paralelo e com mesma ênfase de órgãos sexuais e faces do homem e da mulher em ato sexual. É provavelmente por isso que a mulher foi representada propositalmente de costas para o homem, e também o fato de a perna direita da mulher estar virada para trás de modo antinatural deve servir para mostrar completamente a região de sua cópula.

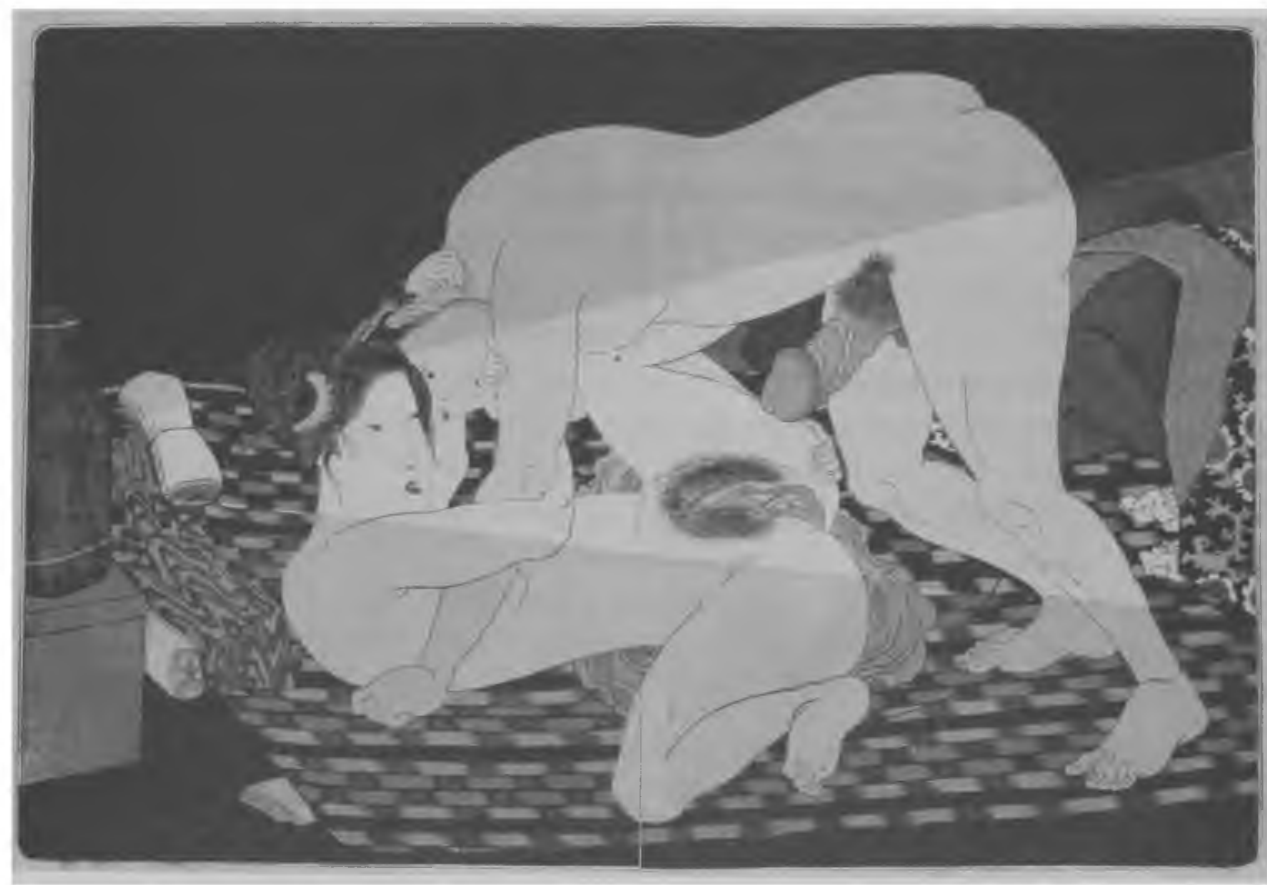

Figura 6 Kachô Yojû Azuma Genji (Genji do Leste, Impressão Poética de Pássaros-e-Flores), $4^{\mathrm{a}}$ imagem do $1^{\circ}$ volume, Utagawa Kunisada (1786 1864), 3 volumes de livro grande multicolorido, ano 8 da era Tenpô (1837), coleção Nichibunken.

Trata-se de uma representação de um quarto de dormir de um casal de meia idade em uma residência geminada pobre da Cidade Baixa de Edo, numa noite de verão. A luz do brilho da luminária próxima ao travesseiro modela vividamente faces e órgãos sexuais 
do casal nu. Pode-se dizer que está claramente expressa a intenção do pintor em mostrar na presente composição, faces e órgãos sexuais de modo paralelo.

(4) "Os amantes das pinturas eróticas são homens e mulheres jovens e velhos, sem discriminação de pobreza ou riqueza"

Tratando-se de pinturas que abordam de modo franco e intrépido o sexo, hoje em dia deve-se pensar que são apenas os homens os seus apreciadores, mas, ao lermos fontes manuscritas e material bibliográfico do período Edo, nota-se que eram realmente variados os apreciadores de shunga, não se tendo restringindo somente aos homens e, além disso, também velhos e jovens, independentemente da idade, se entretiam com o gênero. Mesmo observando suas classes sociais, hoje é sabido que grande variedade de pessoas apreciava verdadeiramente o shunga, a começar pela gente comum das casas geminadas e pelos camponeses das províncias, até os mais refinados intelectuais e daimios famosos.

Em relação à popularização da pintura erótica ukiyo-e entre a gente comum, grande contribuição deu um sistema da época chamado kashihon-ya, casas de empréstimos de livros. Por mais acessíveis que fossem os preços das estampas xilográficas em relação às pinturas, a gente comum certamente não poderia comprar e colecionar novas edições de álbuns e livros impressos que surgiam seguidamente. As casas de empréstimo de livros compravam obras eróticas sempre em novas edições e os dispunham segundo a procura dos clientes. Como os responsáveis por essas casas eram em sua maioria as esposas dos donos ou suas filhas, estas estavam muito familiarizadas com as pinturas eróticas ukiyo-e.

Encontram-se frequentemente nos poemas senryû homens jovens apreciando shunga, mas há também muitos versos que mostram vários tipos de mulheres, a começar por moças e serventes do lar até esposas e viúvas. No fim do período Edo há registros concretos de mulheres apreciando shunga, mas também na obra autobiográfica Vita sexualis de Mori Ôgai, encontram-se registradas circunstâncias em que mulheres em geral estão apreciando pinturas eróticas, em Tsuwano (atual província de Shimane), local que se encontra muito afastado da cidade de Edo.

No tocante à relação entre casas de samurais e pinturas eróticas também era corrente a apreciação, como se pode supor das anotações intituladas Shunshoku shungano hô (Método da Sensual Pintura Erótica), constantes de Gasen, livro didático da família Kanô que se compunha dos pintores oficiais do xogunato de Edo. Encontra-se registrado na obra Abuna-e (Pinturas Picantes) da autoria do pesquisador sobre o período Edo, Mitamura Engyô (1870 1952):

Assim sendo, certamente mesmo hoje devem vir à luz ainda muitas pinturas eróticas do período Edo em acervos de importantes casas de samurais dessa época.

7. Nascido em Tokyo, foi jornalista e monge, até se tornar pesquisador livre, especialmente sobre os usos e costumes, a literatura e o teatro do período Edo. 
Engyô também comunica o seguinte exemplo no tocante a samurais e pinturas eróticas:

"Por outro lado, todos os daimios e todos os samurais hatamoto possuem exemplares de elmos e armaduras, os quais eram obrigatoriamente mandados confeccionar, e tinham o hábito de guardar um rolo de pintura erótica em suas grandes caixas."

Este hábito logo se difundiu também entre os citadinos prósperos, que as transformaram em "amuletos de afastar incêndios", guardando-as em seus depósitos, tendo sido apreciadas, em especial, as pinturas eróticas de Tsukioka Settei (1710 1786), da região de Kamigata (Quioto, Osaka e arredores).

Mas tais pinturas não exerciam somente a função de amuletos ou talismãs, pois também não faltam, por outro lado, registros de que o shunga era verdadeiramente apreciado por uma camada de samurais da época, ou pelos estudiosos do confucionismo, ou ainda pelos filósofos ou diletantes das artes [bunjin]. O grande estudioso confucionista Ogyû Sorai (1666 1728) ${ }^{8}$ teceu elogios ao shunga em um parágrafo de sua obra Kôshi (Confúcio); o idoso conselheiro e diletante das artes Yanagisawa Kien (1704 1758) ${ }^{9}$ do todo poderoso feudo Yamato Kôriyama deixou registradas, em seus escritos, as eficácias do shunga. E, ainda, do mesmo feudo de Yamato Kôriyama, Yamaoka Matsuake $(1726 \sim 1780)^{10}$ noticia uma história em seu diário sobre um empréstimo de "livro-travesseiro"; no campo dos Estudos Vernaculares, Ôta Nanpo $(1749 \sim 1823)^{11}$ colecionou grande número de livros eróticos, a ponto de existir, em seu registro de acervo bibliográfico, 0 item "livros eróticos / shunga"

No diário do oficial xogunal Kawaji Toshiakira $(1801 \sim 1868)^{12}$, proeminente líder da época que se relacionou diretamente com o russo Putjatin ${ }^{13}$ e o americano Perry ${ }^{14}$, encontram-se registrados empréstimos de obras eróticas de Hishikawa Moronobu por importantes servidores do castelo de Edo. É-nos transmitido um fato muito curioso e divertido, pois, de acordo com esta história, no dia seguinte, certo idoso conselheiro, muito respeitável, tomou emprestadas obras

8. Um dos mais influentes estudiosos do confucionismo, dedicou-se exaustivamente aos clássicos chineses, em geral.

9. Yanagisawa Kien dominava as "16 artes", entre elas: confucionismo, budismo, caligrafia, pintura, música.

10. Além dos Estudos Vernaculares, dedicou-se ao confucionismo, escreveu prosa sharebon.

11. Além dos Estudos Vernaculares, Ôta Nanpo compunha "poemas loucos" (kyôka), "poemas loucos chineses" (kyôshibun) e prosa sharebon.

12. Proveniente de Sado, Kawaji Toshiakira escreveu “Diário de Nagasaki” e suicidou-se com uma pistola um dia após a queda do castelo de Edo.

13. Jevfimij Vasil'jevich Putjatin (1804 1883) [Puchâchin] foi embaixador russo, chegou ao Japão em 1853, através de Nagasaki e foi responsável pelos laços de amizade e comércio entre os dois países.

14. Matthew Calbraith Perry (1794 1858) [Perî] foi comandante da esquadra americana que, em 1854, viabilizou a abertura dos portos do Japão ao exterior. 
tais, e a esposa de Toshiakira, ao ouvir que este fora visto subindo imediatamene ao segundo andar para ler tão importantes livros, disse: "Fiquei muito tocada com essa extraordinária história, pois além disso é para rir muito"

Dessa forma, no período Edo, o shunga não era um objeto de especialidade de homens jovens ou de homens dados ao amor, pois era apreciado de modo aberto e por pessoas de diferentes maneiras de pensar, sem se discriminar velhos e jovens, homens e mulheres, ricos e pobres.

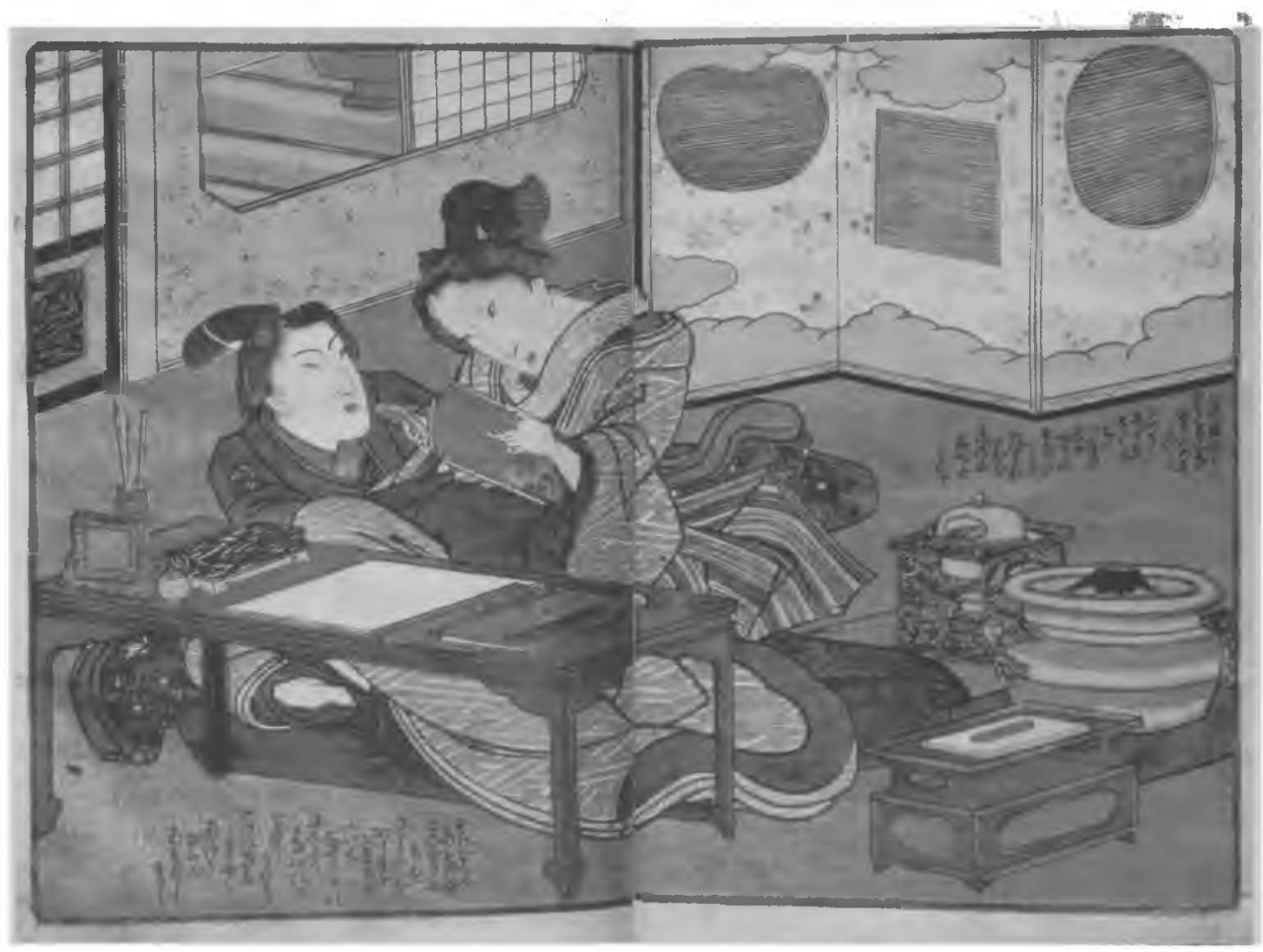

Figura 7 Shunjô Yubi-ningyô (Luxuriosos Fantoches de Dedo), $1^{\mathrm{a}}$ imagem do último volume, Keisai Eisen (1790 1848), 3 volumes de livro de tamanho médio multicoloridos, ano 9 da era Tenpô (1838).

Trata-se de uma cena em que uma ama de leite de uma casa própera está ensinando ao patrãozinho a ler e escrever. Entretanto, ao lermos o texto inserido:

Babá: “Tenha a gentileza de brincar com isto. Aqui está desenhado que é para colocar o dedo deste jeito. Depois, é para abrir logo e brincar. (...) No texto aqui em cima da pintura também está escrito uma coisa muito boa. Ee-já... faça assim, faça desta forma como na pintura seguinte. Ai! Meu rosto ficou todo vermelho..." 
Quer dizer, esta babá está usando como material didático um livro erótico ilustrado com shunga. E parece, de alguma forma, que quem foi primeiro tomado pela luxúria foi justamente ela. Provavelmente esta imagem representa uma história nada oficial [urabanashi] da educação que era praticada nas boas casas da época.

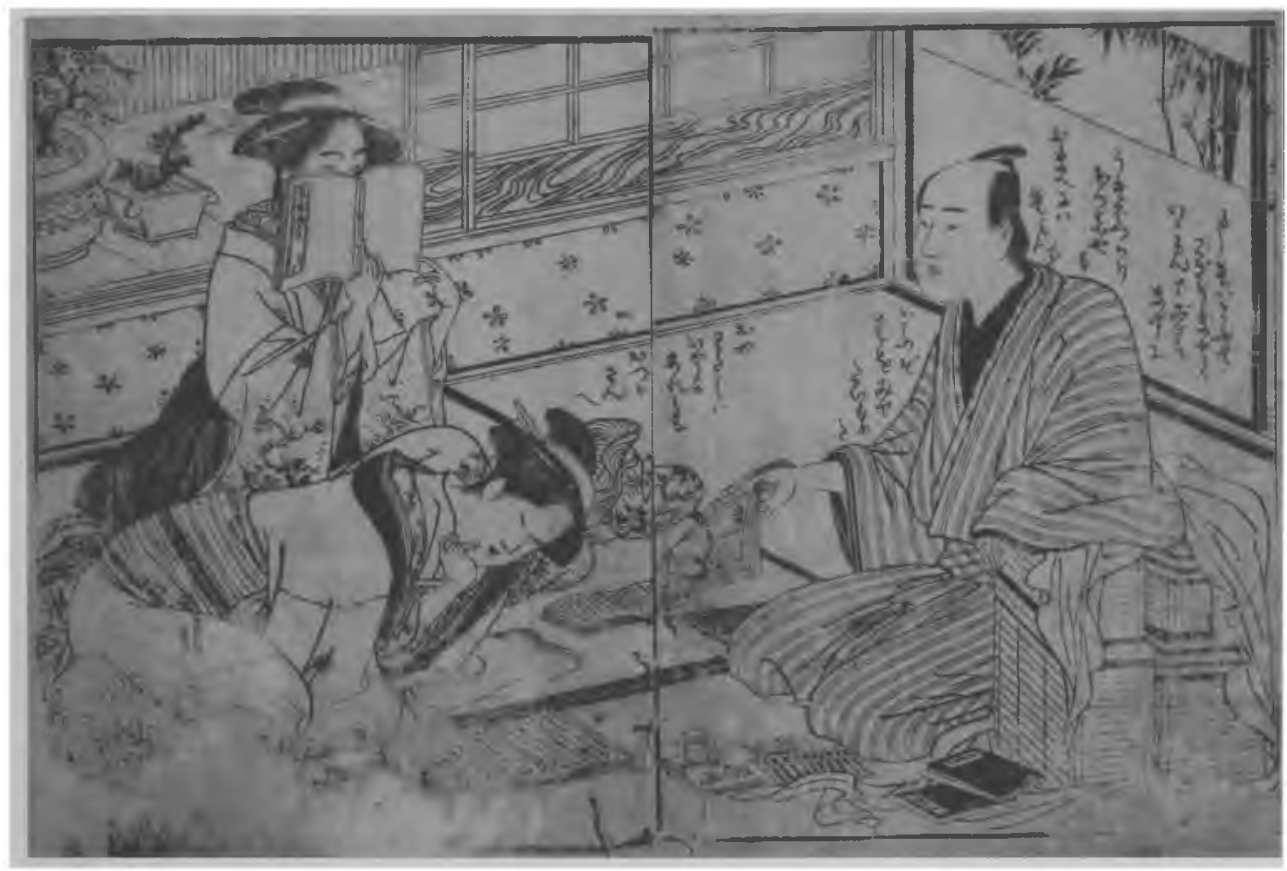

Figura 8 Edo Miyage (Belo Presente Florido da Sensual Pintura de Edo), $4^{\mathrm{a}}$ imagem do $2^{\circ}$ volume, Katsukawa Shunchô (? ?), 3 volumes de livro de tamanho médio em preto e branco, ano 7 da era Tenmei (1787), coleção Nichibunken.

Trata-se de uma imagem em que um funcionário ambulante da casa de empréstimo de livros está mostrando um volume a uma mãe e sua filha. O que foi aberto e está sendo mostrado é um livro erótico que contém shunga. Diz-se que tais funcionários que serviam às casas, atendendo aos pedidos dos seus clientes, sempre deixavam preparados livros eróticos recém-lançados.

Funcionário: "Que tal este daqui? Trata-se de um livro muito bom, sabe?"

Filha: "Eu não gosto nada! Mamãe! Dá uma olhada naquilo! (...)"

Funcionário: "A senhorita não está dizendo a verdade! É uma obra que queria muito lhe mostrar!"

Nesta cena, o funcionário está provavelmente a mostrar uma pintura erótica à moça. Ele parece estar a flertar com ela utilizando o livro erótico, que é seu instrumento de trabalho comercial. 
Assim, desta forma, podemos então concluir que a característica principal da pintura erótica ukiyo-e não se encontra na representação de usos e costumes sexuais ou de peculiaridades de um mundo pré-estabelecido, mas na descrição minuciosa de variados e totalmente casuais hábitos amorosos da gente mais comum.

(Tradução e notas de Madalena N. H. Cordaro) 


\section{ADENDO}

A prática sexual dos comuns no período Edo (1603-1867) representada no ukiyo-e shunga

1 Quando se refere o termo shunga, logo vêm à mente as estampas eróticas de pintores tais como Utamaro ou Hokusai, do período Edo, mas no Japão, o gênero já pode ser traçado desde o período Heian. É digno de profundo interesse que, mesmo em relação ao shunga do período Heian (794-1185), era método estabelecido que a representação dos órgãos sexuais, principalmente o masculino, fosse enfatizada em proporções generosas. Isso quer dizer que, na pintura, não se representava o que se via na realidade, mas se tinha uma percepção de um mundo de "coisas inventadas" [ezoragoto], sendo desenhada, em suma, uma realidade psicológica.

2 Nos dias de hoje é comum apontar shunga com outros termos, como "pintura secreta" [higa] ou "pintura caricatura secreta" [higiga], mas no período Edo o gênero era referido como "pintura travesseiro" [makura-e], ou "pintura riso" [warai-e]. Por outro lado, o livro erótico era chamado de "brochura travesseiro" [makura-zôshi], ou então "livro riso" [waraibon]. Pensa-se, especialmente, que na designação de "pintura riso" e "livro riso" se expressa o modo de ver o sexo dos japoneses desde a antiguidade, não somente o dos habitantes de Edo.

3 No caso da representação no gênero shunga, é comum pensar que se trata principalmente de usos e costumes de cortesãs e seus clientes nas áreas de prazeres ou de jogos amorosos selvagens de uma classe ociosa e apreciadora do sexo; entretanto, o que se representa de modo especial no ukiyo-e shunga, em mais de noventa por cento dos casos, é o universo de usos e costumes do sexo das camadas comuns da população. Entram em cena de crianças a velhos, homens e mulheres de todas as idades e posições sociais, havendo situações idiotas que chegam ao cúmulo do absurdo com o propósito de despertar o riso, e tenho a impressão de que grande parte de cenas semelhantes ainda hoje deve existir em vários locais. 
4 Se nos restringirmos a apenas olhar as imagens shunga não compreenderemos seus pontos mais interessantes. $\mathrm{Na}$ maior parte das imagens shunga há palavras inseridas que indicam o título ou o tema, ou pequenas histórias, ou, ainda, o que se chama "texto inserido" [kakiire] que expressa os diálogos entre os personagens representados. Quando se lêem esses textos, passa-se a se compreender realmente bem a posição social e a relação entre os personagens, ou, ainda, as causas de terem chegado a tal situação. Se lermos os "textos inseridos", ao mesmo tempo em que potencializamos nosso interesse pelas imagens shunga, podemos ainda dizer que passaremos a compreender com mais fidelidade a percepção sexual dos habitantes de Edo.

5 No período Edo, o shunga era chamado, de modo geral, de "pintura riso" e, certamente, na maior parte do ukiyo-e shunga, encontra-se submersa a tendência para o "riso", mas, para além dessa inclinação, tal nomeação não se restringe somente aos homens dessa época, mas expressa o fato de que, desde muito antes, os japoneses viam o "sexo" como coisa que deveria fundamentalmente provocar o riso. Penso que essa postura de compreender o "sexo" do ponto de vista do "riso" difere fundamentalmente da corrente atual de pensamento ocidental que tem sido predominante na Idade Moderna, que age como se o "sexo" fosse um pecado original, ou um tabu.

6 Como característica de representação do shunga, o que se diz muito comumente não só no Japão como também no ocidente, é que se enfatizam os órgãos sexuais masculinos; entretanto, se refletirmos um pouco, penso que compreendemos logo que se somente estes tivessem sido enfatizados, não haveria condições de se representar o intercurso sexual. Como se pode apreender ao se observar atentamente essas imagens eróticas, não são somente os órgãos sexuais masculinos, mas também os femininos, que são enfatizados em suas dimensões. Além disso, não são somente os órgãos sexuais femininos e masculinos que são importantes, mas pode-se dizer que quase que absolutamente obrigatória é também a representação de seus rostos, e com iguais proporções e com mesma sutileza e minúcia. Pode-se dizer que uma característica fundamental do shunga japonês reside no fato de se representar em justaposição e em comparação fundamental de mesma natureza tanto os rostos quanto os órgãos sexuais de homens e mulheres, chegando-se até o ponto de se ignorar a expressão natural dos corpos. Penso que, nessa forma de expressão, há uma conotação realmente sugestiva mesmo enquanto existência humana.

7 Há desde abordagens que compreendem o shunga a partir da concepção pornográfica moderna de se caracterizar em grande parte por ser uma representação de um sexo desavergonhado até as que dizem que tais imagens não passariam de objeto para ser utilizado na prática da masturbação, em especial por homens jovens; entretanto, se formos averiguar vários materiais, não nos restringindo somente ao shunga, podemos afirmar que as imagens eróticas eram apreciadas amplamente por homens e mulheres 
de todas as idades e, em particular, sem fronteiras econômicas entre ricos e pobres. Por causa disso, há também os que criticam os japoneses por julgarem que eles são uma raça inigualável de apreciadores do sexo, mas isto não passa de um julgamento apressado, pois, fundamentalmente, o modo de pensar o "sexo" não é, como o dos ocidentais, tão rígido, devendo ser compreendido como fonte de alegria e como sendo o mais importante elemento da raça humana, em total adaptação a situações verdadeiras.

8 Como o Japão era um país feudal, os homens eram o ponto central dos desejos, mesmo no shunga, e dever-se-ia pressupor que fossem mais numerosas as imagens em que as mulheres não passassem de joguetes como objetos sexuais dos homens; entretanto, ao prosseguirmos em analisar o seu conteúdo, vemos que também muito numerosos são os desenhos em que as mulheres são representadas de modo bastante ativo. Além disso, pode-se dizer que o ideal do intercurso de homens e mulheres no shunga encontra-se na harmonia entre eles, devendo ambos atingir juntos o êxtase.

9 Na Europa e nos Estados Unidos, em especial, parece que existe um fortíssimo sentimento de repúdio, a ponto de se atingir a anomalia, quando aparecem em cena crianças em situações de amor e sexo de adultos, mas no shunga, aparecem em inúmeras cenas desde bebês ainda lactantes até pueris meninos e meninas. Entretanto, não que as crianças sejam absolutamente representadas como objetos eróticos, mas elas se encontram inseridas na vida cotidiana da gente comum de modo o mais natural, ou, ainda, mostram suas faces como conseqüência acidental das circunstâncias. Podese pensar que isto se tenha dado devido à percepção de que os japoneses não tinham uma consciência moral religiosa em relação ao sexo e, por isto, não tenha havido uma necessidade particular de encará-lo como objeto de segredo.

10 Como grande característica do esquema de shunga, são muito numerosos os livros paródicos que remetem aos muitos escritos dos clássicos japoneses e chineses, aos poemas japoneses e chineses clássicos, ou seja, a livros de toda a espécie e, para devidamente apreciar tal tendência, torna-se necessário ter conhecimento das sinopses de todos os livros clássicos que lhes serviam de base. Freqüentemente se questiona se os homens comuns que apreciavam os livros eróticos [ehon] e as estampas shunga possuíam tais vastos conhecimentos, mas em especial desde os meados do período Edo, espalhavam-se por todo o país as instalações de educação básica, conhecidas como terakoya, e, portanto, o grau de alfabetização da época era relativamente alto se comparado ao mundo, podendo-se concluir que, a se começar obviamente pela leitura e escrita dos fonemas da época [hentaigana] nos livros e brochuras utilizados nos livros eróticos [ehon] e nas estampas shunga, existia grande grau de conhecimento em relação à vida prática e também aos episódios e escritos clássicos os mais variados. 